\title{
Volatile Compounds and Antioxidant Capacity of the Bio-Oil Obtained by Pyrolysis of Japanese Red Pine (Pinus Densiflora Siebold and Zucc.)
}

\author{
Jayanta Kumar Patra ${ }^{1}$, Sung Hong Kim ${ }^{2}$, Hyewon Hwang ${ }^{3}$, Joon Weon Choi ${ }^{3,4, *}$ and \\ Kwang-Hyun Baek ${ }^{1, *}$
}

1 School of Biotechnology, Yeungnam University, Gyeongsan, Gyeongbuk 712-749, Korea; E-Mail: jkpatra@ynu.ac.kr

2 Analysis Research Division, Daegu Center, Korea Basic Science Institute, Daegu 702-701, Korea; E-Mail: sunghkim@kbsi.re.kr

3 Department of Forest Sciences, College of Agriculture and Life Science, Seoul National University, Seoul 151-921, Korea; E-Mail: ch11309@naver.com

4 Institute of Green-Bio Science and Technology, Seoul National University, Pyeongchang, Gangwon-do 232-916, Korea

* Authors to whom correspondence should be addressed; E-Mails: cjw@snu.ac.kr (J.W.C.); khbaek@ynu.ac.kr (K.-H.B.); Tel.: +82-2-880-4788 (J.W.C.); +82-53-810-3029 (K.-H.B.); Fax: +82-2-873-2318 (J.W.C.); +82-53-810-4769 (K.-H.B.).

Academic Editor: Derek J. McPhee

Received: 16 January 2015 / Accepted: 25 February 2015 / Published: 2 March 2015

\begin{abstract}
In the present study, sawdust bio-oil (SBO) manufactured by fast pyrolysis of Japanese red pine (Pinus densiflora Siebold and Zucc.) sawdust was analyzed for its volatile chemical compound composition and evaluated for its free radical scavenging potential, inhibition of lipid peroxidation and reducing power. Gas chromatography and mass spectroscopy revealed 29 volatile compounds, comprising $97.6 \%$ of the total volatile compounds in SBO. The antioxidant potential of SBO in terms of $\mathrm{IC}_{50}$ values was $48.44 \mu \mathrm{g} / \mathrm{mL}$ for hydroxyl radical scavenging, $89.52 \mu \mathrm{g} / \mathrm{mL}$ for 1,1-diphenyl-2-picrylhydraxyl radical scavenging, $94.23 \mu \mathrm{g} / \mathrm{mL}$ for 2,2'-azino-bis[3-ethylbenzothiazoline-6-sulphonic acid] radical scavenging, and $136.06 \mu \mathrm{g} / \mathrm{mL}$ for superoxide radical scavenging activity. The total phenol content in SBO was $5.7 \%$ gallic acid equivalent. Based on the composition of its volatile compounds, high free radical scavenging potential and antioxidant properties, SBO
\end{abstract}


could be used as a source of antioxidant compounds, flavoring agents and nutraceuticals in the food, pharmaceutical, and cosmetic industries.

Keywords: antioxidants; bio-oil; Japanese red pine; pyrolysis; reactive oxygen species

\section{Introduction}

Reactive oxygen species (ROS) play important roles in modulation of various physiological and metabolic functions of the body [1]. ROS include free radicals such as hydroxyl $\left(\mathrm{OH}^{\circ}\right)$ and superoxide anion $\left(\mathrm{O}_{2}^{-}\right)$, as well as non-free radicals such as $\mathrm{H}_{2} \mathrm{O}_{2}$ and singlet oxygen $\left({ }^{1} \mathrm{O}_{2}\right)$ [2,3]. To protect against the adverse effects of ROS in living systems, organisms adopt antioxidant defense mechanisms that directly scavenge or prevent the generation of ROS [1]. Nevertheless, excessive generation of ROS in living organisms can overcome these antioxidant defense mechanisms, leading to oxidative stress [4]. This stress then causes damage to different biomolecules such as lipids, proteins, carbohydrates and nucleic acids, leading to various types of degenerative diseases such as cancer, aging, atherosclerosis, cardiovascular disorders, neurodegenerative disorders and inflammation [5-7].

ROS can cause lipid peroxidation in foods, which leads to their deterioration and reduced quality $[8,9]$. To protect food items from the adverse effects of oxidative damage caused by ROS, various synthetic antioxidants such as butylated hydroxytoluene (BHT), butylated hydroxyanisole (BHA) and propyl gallate are commonly added [6]. However, owing to the toxicity and potential health hazards associated with synthetic antioxidants, there has been growing interest in finding natural substances with antioxidant activities [9-11].

Plants and their products have been shown to exert antioxidant activity against ROS that allows their effective use as food preservatives, dietary supplements, and food flavoring agents $[12,13]$. Japanese red pine (Pinus densiflora Siebold and Zucc.) is an evergreen tree belonging to the family Pinaceae that is widely distributed in Korea [14,15]. The leaves and bark have been used as a source of food additives, food ingredients and folk medicines used throughout Eastern Asia for the treatment of hepatosis, arteriosclerosis and various neurological disorders [14,15]. The leaves of Japanese red pine contain high amounts of volatile compounds with potent biological activities, including antioxidant activities [16]. The bark extracts of $P$. densiflora displayed potential antioxidative and DNA protection activity thanks to their rich content of phenolic compounds, such as procyanidins, phenolic acids and bioflavonoids [17,18]. Hot water extracts of Pinus species rich in low molecular weight tannins and phenylpropenoid monomers possess strong antioxidant scavenging potential [19]. The needles of $P$. densiflora contain high amounts of proanthocyanidins and catechins, which have strong antioxidant potential [20]. Bioflavonoids such as phenols and polyphenols (e.g., catechin, taxifolin, epicatechin), condensed flavonoids (e.g., procyanidin, B1, B3 and B7) and phenolic acids (e.g., ferrulic acid, caffeic acid and $p$-hydroxybenzoic acids) extracted from different species of Pinus have been reported to possess strong antioxidant potentials [21-23].

Sawdust obtained as a byproduct of cutting, drilling, and grinding of wood can be further utilized for the production of naturally occurring safe and potentially useful products that can be utilized in various sectors like foods, cosmetics and pharmaceuticals [24]. Bio-oil (BO) is a liquid product 
produced by the pyrolysis of biomass materials such as agricultural crops, algal biomass, municipal wastes, and agricultural and forestry by-products (e.g., wood, sugar cane bagasse, rice husks and straw, and coconut fiber) via thermo-chemical/pyrolysis processes $[25,26]$. BO has been developed for use as an alternative energy source, but also shown to be useful as a source of antioxidant compounds, food additives, and flavor agents [27-33]. Moreover, BOs manufactured from different sources have been reported to have bactericidal, insecticidal and fungicidal properties [31,34]. BOs are rich in phenolic and tannins, along with other volatile compounds such as furan and furan derivatives, therefore, they have high medicinal potential too [35].

In the present study, the sawdust of Japanese red pine was used to produce a sawdust-derived bio-oil (SBO). The chemical composition of the volatile compounds, free radical scavenging and antioxidant potentials of the SBO were then evaluated. Owing to the complicated nature of different types of antioxidants and their reactivity, and since a single antioxidant assay can predict only a reduced view of the antioxidant properties in a sample [36,37], different in vitro methods were applied in the present study to evaluate the antioxidant potential of SBO.

\section{Results and Discussion}

\subsection{Physical Properties of SBO}

The elemental composition, water content, viscosity, total acid number (TAN), and higher heating values (HHV) of SBO are given in Table 1. Compared to typical data describing BOs from the other sources [32], the results indicated that the SBO used in this study contained slightly more carbon (50.6\%) and less oxygen (41.8\%). Accordingly, HHV based on analytical data also slightly increased. The water content and TAN of SBO were similar to those of the other BOs [38], while the viscosity was low (12 cSt), indicating that SBO was easy to handle.

Table 1. Physical properties of Japanese red pine sawdust bio-oil (SBO).

\begin{tabular}{cc}
\hline Elemental Analysis & Amount \\
\hline $\mathrm{C}(\%)$ & 50.6 \\
$\mathrm{H}(\%)$ & 6.9 \\
$\mathrm{~N}(\%)$ & 0.7 \\
O (by difference) $(\%)$ & 41.8 \\
\hline Water content (wt\%) & 23.6 \\
Viscosity (cSt) & 12 \\
TAN (mg/g KOH) & 74.4 \\
HHV (MJ/kg) & 20.7 \\
\hline
\end{tabular}

\subsection{Chemical Composition of SBO}

GC-MS analysis revealed the chemical composition of volatile compounds in SBO. The chemical profiles of different types of BO based on the GC-MS spectra have previously been reported [39-41]. The chemical composition of $\mathrm{BO}$ is greatly influenced by the type of raw material used for extraction of BO [42]. For this study, a total of 29 different compounds comprising $97.6 \%$ of the volatile compounds in the SBO were selected and identified (Figure 1 and Table 2). The components of SBO mainly 
comprised aldehydes, alcohols, acids, ether, phenols, and phenol derivatives. Among these, trimethyl orthoacetate (12.8\%), 4-oxo-5-methoxy-2-penten-5-olide (8.7\%), 1,4-methanoazulene $(8.4 \%), p$-cresol $(6.0 \%)$ and benzenemethanamine $(5.5 \%)$ were the top-five most abundant compounds. Acids, aldehydes, alkanes, benzenes, furans, naphthalenes, alcohols and phenols have also been reported to be present in the pine needles of Japanese red pine [14,15]. Some volatile compounds present in the pine needle powder of Japanese red pine, such as 2-methylfuran, $p$-cresol, phenol, 2(5H)-furanone, benzaldehyde and benzenemethanol, were also present in SBO. However, SBO contained additional volatile compounds not present in the pine needle powder (Table 2), possibly due to differences in the type of raw materials used to manufacture the SBO and conversion or degradation of organic matter into numerous small molecules during the fast pyrolysis process used for the manufacture of BO [37]. Volatile compounds such as furan and furan derivatives, ethylresorcinol, cresol, methanoazulene and trimethyl orthoacetate present in SBO have medicinal importance (Figure 2). Furan and furan derivatives form the basic skeleton of numerous compounds with cardiovascular activities. These compounds are widely used for their antiviral, anti-inflammatory, antibacterial, antifungal, antitumor, and antihyperglycemic properties, as well as in the treatment of ventricular and atrial fibrillation [43-45]. Ethylresorcinol possesses hypopigmentary and antioxidant properties [46], and cresols are used in the preparation of antioxidants and as abortives, diaphoretics, and emmenagogeous drugs [43,44,47,48]. 4-oxo-5-methoxy-2-penten-5-olide previously identified as a component of honey has potential antiproliferative potential [48]. Further, compounds present in SBO in higher concentrations can be upgraded to other useful compounds by the process of molecular distillation technology and can be utilized in pharmaceutical industries [32]. $p$-Cresol, found in high concentration $(6.0 \%)$, can be converted to other usable antioxidants and diphenol antioxidants with relatively low toxicity [27] by the tert-butylation procedure using a Bronsted acid functionalized ionic liquid, and those conversion products can be potentially used in the food, pharmaceutical and cosmetic industries [30]. Trimethyl orthoacetate present in SBO can be used in the pharmaceutical industry for the esterification of ferulic acid to produce more potent antioxidants [28,29].

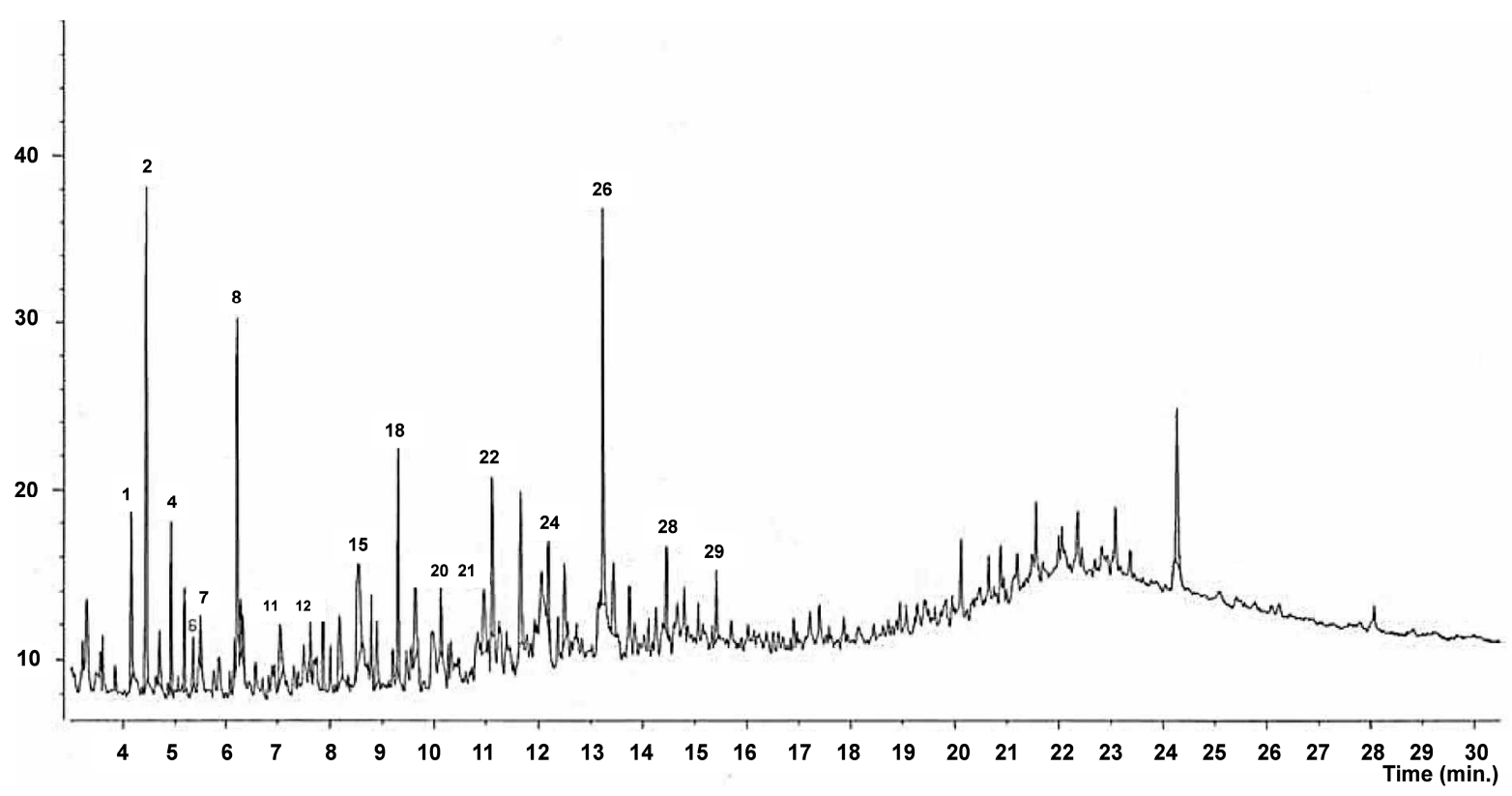

Figure 1. GC-MS spectra of Japanese red pine sawdust bio-oil (SBO). 
Table 2. Major components of Japanese red pine sawdust bio-oil (SBO) based on GC-MS analysis.

\begin{tabular}{|c|c|c|c|c|c|}
\hline No. & SI ${ }^{a}$ & $\mathbf{R T}^{\mathbf{b}}$ & Compound $^{\mathrm{c}}$ & Composition (\%) & Identification Method $^{d}$ \\
\hline 1 & 554 & 4.15 & 2-Methylfuran & 4.28 & EI-MS \\
\hline 2 & 676 & 4.45 & Trimethyl orthoacetate & 12.78 & EI-MS \\
\hline 3 & 773 & 4.70 & Acetol acetate & 1.30 & EI-MS \\
\hline 4 & 812 & 4.92 & 2,5-Dimethoxytetrahydrofuran & 2.92 & EI-MS \\
\hline 5 & 823 & 5.35 & 2-Methyl-2-cyclopentenone & 1.17 & EI-MS \\
\hline 6 & 897 & 5.48 & 2(5H)-Furanone & 1.01 & EI-MS \\
\hline 7 & 782 & 6.23 & 4-Oxo-5-methoxy-2-penten-5-olide & 8.72 & EI-MS \\
\hline 8 & 533 & 6.30 & Erythrite tetramethyl ether & 1.38 & EI-MS \\
\hline 9 & 534 & 6.33 & 2,3,4-Trimethylfuran & 1.07 & EI-MS \\
\hline 10 & 803 & 7.05 & Phenol & 2.19 & EI-MS \\
\hline 11 & 600 & 7.63 & Hexanal dimethyl acetal & 0.95 & EI-MS \\
\hline 12 & 563 & 7.88 & $1,1, \mathrm{~N}, \mathrm{~N}$-(tetramethylbuta)-1,3-diene-4-amine & 2.08 & EI-MS \\
\hline 13 & 891 & 8.18 & $o$-Cresol & 2.79 & EI-MS \\
\hline 14 & 763 & 8.54 & $p$-Cresol & 6.02 & EI-MS \\
\hline 15 & 645 & 8.79 & Benzaldehyde dimethyl acetal & 1.18 & EI-MS \\
\hline 16 & 455 & 8.89 & Butanoic acid & 1.68 & EI-MS \\
\hline 17 & 577 & 9.31 & Hexanalldimethyl acetal & 4.90 & EI-MS \\
\hline 18 & 847 & 9.63 & 2,5-Xylene & 3.20 & EI-MS \\
\hline 19 & 716 & 10.13 & 4-Ethylresorcinol & 1.32 & EI-MS \\
\hline 20 & 809 & 10.96 & $p$-Ethylanisole & 2.62 & EI-MS \\
\hline 21 & 902 & 11.11 & 5,4-Dimethyl-2-methylbibenzyl & 4.10 & EI-MS \\
\hline 22 & 684 & 11.66 & 5-(Hydroxymethyl)-2-(dimethoxymethyl) furan & 4.75 & EI-MS \\
\hline 23 & 671 & 12.19 & 1,3-Bis(trimethylsiloxy)benzene & 2.36 & EI-MS \\
\hline 24 & 613 & 12.49 & 2-Methoxy-6-(1-propenol) phenol & 2.48 & EI-MS \\
\hline 25 & 871 & 13.24 & 1,4-Methanoazulene & 8.44 & EI-MS \\
\hline 26 & 357 & 13.44 & 6-Methyl-4-indanol & 2.60 & EI-MS \\
\hline 27 & 626 & 14.46 & 4-(Phenylmethyl)benzenemethanol & 2.35 & EI-MS \\
\hline 28 & 748 & 15.42 & Napthalene & 1.50 & EI-MS \\
\hline 29 & 493 & 24.28 & Benzenemethanamine & 5.48 & EI-MS \\
\hline
\end{tabular}

a SI-Library search purity value; ${ }^{\mathrm{b}}$ RT-Retention time; ${ }^{\mathrm{c}}$ Compounds listed in order of elution; ${ }^{\mathrm{d}}$ Identification based on computer matching of electron ionization mass spectra using Wiley and NIST libraries for the GC-MS system.

SBO can be utilized as food additive giving smoked, roasted and grilled flavors to food products [49]. SBO was also found to be rich in various types of volatile compounds with medicinal potential, therefore, further investigation of its role as a source of antioxidant compounds could be beneficial for its application in the food sector as a food additive, flavoring agent, food preservation and possibly in pharmaceutical and cosmetic industries. 

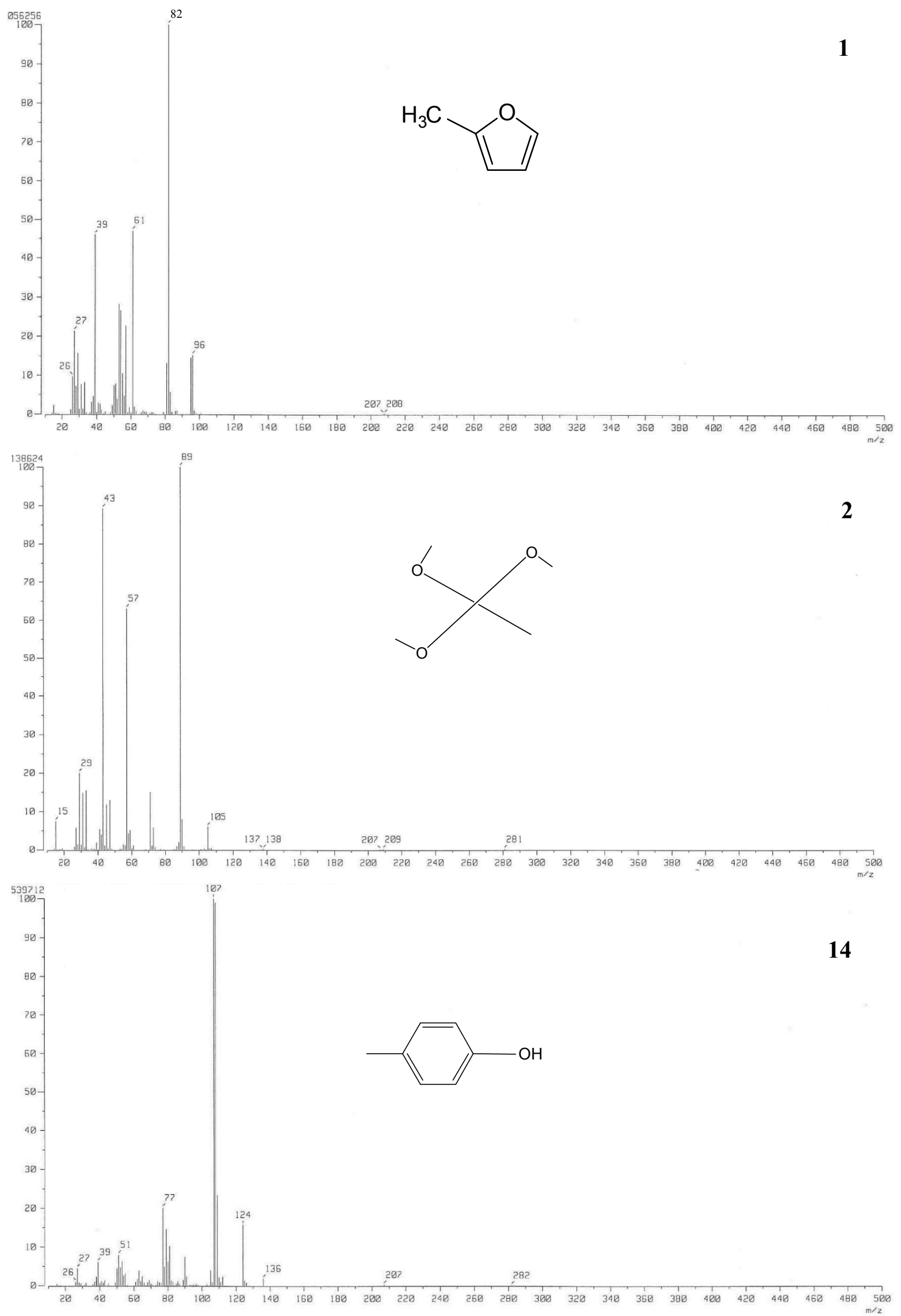

Figure 2. Cont. 

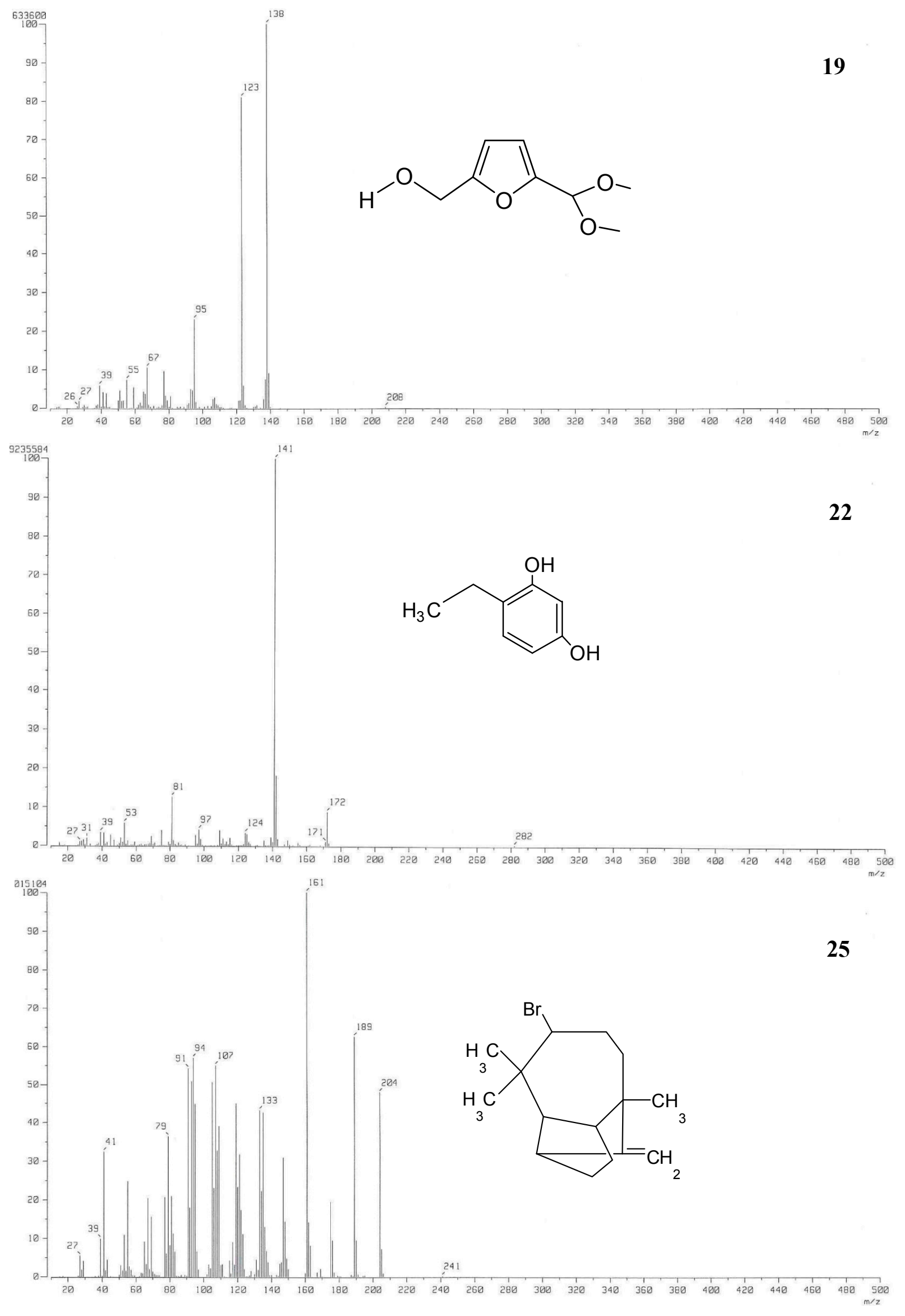

Figure 2. Chemical structure and spectra of some medicinally important compounds present in Japanese red pine sawdust bio-oil (SBO). 


\subsection{DPPH Free Radical Scavenging Activity of SBO}

The DPPH free radical scavenging potential of SBO is presented in Table 3. The concentration of SBO and gallic acid exerting 50\% DPPH scavenging potential is known as its $\mathrm{IC}_{50}$ value and was found out to be $89.52 \mu \mathrm{g} / \mathrm{mL}$ and $21.73 \mu \mathrm{g} / \mathrm{mL}$ respectively (Table 3 ). There was a significant decrease in the concentration of DPPH radical as the concentration of SBO increased due to its ability to scavenge free radicals. DPPH radical is considered a model liphophilic radical; therefore, the scavenging activity of SBO is attributed to its ability to donate hydrogen ions or electrons to DPPH to neutralize free radicals [1]. However, its effects may be due to its inhibitory effect on the free radicals, particularly the peroxy radicals, which are the propagators of lipid peroxidation [50].

Table 3. Free radical scavenging potential of Japanese red pine sawdust bio-oil (SBO).

\begin{tabular}{lccccc}
\hline Sample & $\begin{array}{c}\text { DPPH Free Radical } \\
\text { Scavenging }\end{array}$ & $\begin{array}{c}\text { ABTS Free Radical } \\
\text { Scavenging }\end{array}$ & $\begin{array}{c}\text { Hydroxyl Radical } \\
\text { Scavenging }\end{array}$ & $\begin{array}{c}\text { Superoxide Anion } \\
\text { Scavenging }\end{array}$ & $\begin{array}{c}\text { Nitric Oxide } \\
\text { Scavenging }\end{array}$ \\
\hline SBO & $89.52^{*}$ & 94.23 & 48.44 & 136.06 & 362.45 \\
Gallic acid & 21.73 & 4.48 & 3.99 & 25.08 & 52.59 \\
\hline
\end{tabular}

* Data are expressed in terms of $\mathrm{IC}_{50}$ values $(\mu \mathrm{g} / \mathrm{mL})$.

\subsection{ABTS Free Radical Scavenging Activity of SBO}

The generation of ABTS radical cations is the basis of an important spectrophotometric method for determination of the antioxidant potential of various natural substances [51]. The ABTS free radical scavenging potential of SBO is presented in Table 3. The $\mathrm{IC}_{50}$ value of SBO and the reference compound, gallic acid was found out to be $94.23 \mu \mathrm{g} / \mathrm{mL}$ and $4.48 \mu \mathrm{g} / \mathrm{mL}$ respectively (Table 3). Various factors, including solubility of SBO, bioactive compounds present in it and the stereoselectivity of the radicals might be responsible for its ABTS radical scavenging potential [52,53]. Though SBO exerted less scavenging activity than the reference compound, it might still be useful as a valuable antioxidant resource with various applications, especially in the food and cosmetic industries considering its cost effectiveness.

\subsection{Hydroxyl Radical Scavenging Activity of SBO}

The hydroxyl radical scavenging activity of SBO in terms of $\mathrm{IC}_{50}$ was $48.44 \mu \mathrm{g} / \mathrm{mL}$, while that of gallic acid was $3.99 \mu \mathrm{g} / \mathrm{mL}$ (Table 3). Hydroxyl radical is a highly reactive oxygen free radical that is responsible for various types of cellular damage and lipid peroxidation in living organisms and foods [54]. Accordingly, SBO with high hydroxyl radical scavenging potential can further be exploited for its potential application as a food preservative to protect food products from oxidative damage-related issues. Nowadays, consumers are more concerned about the use of synthetic chemicals by food industry in flavoring, preserving and processing $[55,56]$, therefore, the strong hydroxyl potential of SBO could make it an alternative for use as an antioxidant by the food industry. 


\subsection{Superoxide Anion Scavenging Activity of $S B O$}

As shown in Table 3, SBO and gallic acid scavenged superoxide anions effectively. The IC 50 value of SBO and gallic acid was $136.06 \mu \mathrm{g} / \mathrm{mL}$ and $25.08 \mu \mathrm{g} / \mathrm{mL}$, respectively. Superoxide anions are the precursors to reactive free radicals, which deteriorate various biological macromolecules, thereby inducing tissue damage [57]. Superoxide anion has been implicated in several pathophysiological processes owing to its transformation into more reactive species such as hydroxyl radicals, which are responsible for lipid peroxidation, and singlet oxygens, which cause oxidative damage to DNA, lipids and proteins [50,58]. The effective superoxide scavenging potential of SBO could make it a potential ingredient for the food, pharmaceutical and cosmetic industries as an effective antioxidant compound.

\subsection{Nitric Oxide Scavenging Activity of SBO}

SBO and gallic acid showed $\mathrm{IC}_{50}$ values of $362.45 \mu \mathrm{g} / \mathrm{mL}$ and $52.59 \mu \mathrm{g} / \mathrm{mL}$, respectively (Table 3). SBO showed comparatively less nitric oxide scavenging potentials than gallic acid. Under aerobic conditions, endogenously generated nitric oxide is a very unstable species involved in the regulation of many physiological processes that lead to inflammation, vasodilatation and immune regulation; thus, it is associated with cancer and inflammatory conditions [59]. The activity of SBO in the present study may have been due to the presence of antioxidant compounds that compete with oxygen to react with nitric oxide and inhibit the generation of nitrite. Nitric oxide produced by UV radiation mediates a remarkably diverse and complex range of biological functions in the skin. Especially, with the presence of superoxide radical nitric oxide can form highly reactive peroxynitrite, leading to nitrosation of tyrosine, breakage of DNA strand and skin aging [60,61]. Thus the potential nitric oxide scavenging effect of SBO could make it a suitable candidate for cosmetic industry in the production of sun cream lotions and anti-aging formulations [62].

\subsection{Inhibition of Lipid Peroxidation Activity of SBO}

The inhibition of the lipid peroxidation potential of both SBO and gallic acid is presented in Figure 3 . Both SBO and gallic acid showed significant inhibition of lipid peroxidation of $44.1 \%$ and $49.8 \%$ at $100 \mu \mathrm{g} / \mathrm{mL}$ and $10 \mu \mathrm{g} / \mathrm{mL}$, respectively. There is evidence that lipid peroxidation is responsible for different types of food deterioration processes affecting color, texture, flavor, nutraceutical and nutritional values of food and various food products [24]. The modifications of low density lipoproteins by oxidative process play a major role in causing atherosclerosis [24,63], but this modifications of low density lipoproteins can be overcome by the addition of antioxidants [64].

Due to the high capacity for the inhibition of lipid peroxidation by SBO, it can be used as an alternative to synthetic preservatives and antioxidants commonly used by food industries to preserve foods and increase their shelf life and may also have applications in the development of drugs related to oxidative stress and lipid peroxidation. The skin is rich in lipids which are sensitive to oxidative processes [65], thus SBO with higher lipid peroxidation inhibitory activity could be utilized for the formulation of various skin care, anti-aging and anti-wrinkle products in the cosmetic industry. 

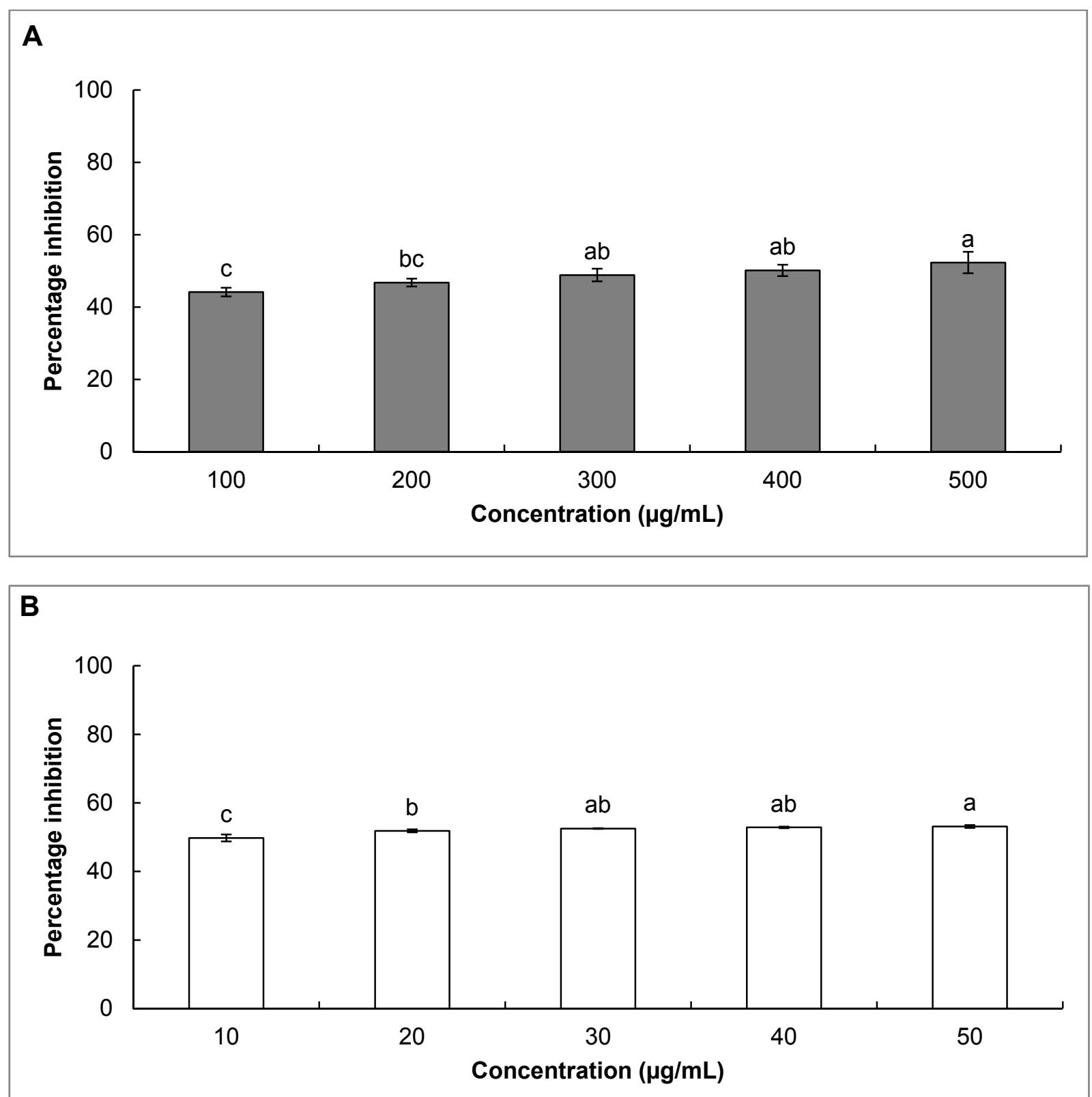

Figure 3. Inhibition of lipid peroxidation by (A) Japanese red pine sawdust bio-oil (SBO) and (B) gallic acid as a reference. Columns with different superscript letters indicate a significant difference at $p<0.05$.

\subsection{Reducing Power and Total Phenol Content of SBO}

Another reaction pathway in the donation of electrons is the reduction of an oxidized antioxidant molecule to regenerate the active reduced antioxidants [36]. Determination of reducing power is an important aspect for estimation of antioxidant potential of any sample. As shown in Figure 4, SBO and gallic acid displayed high reducing power as evident from the increased absorbance values, indicating its strong reduction capability. The antioxidant potential of any compound is mainly due to its redox properties, which play an important role in neutralizing free radicals and quenching singlet oxygen [66]. It has been suggested that there is a direct relationship between antioxidant potential and the reducing power of certain biological samples [67]. 

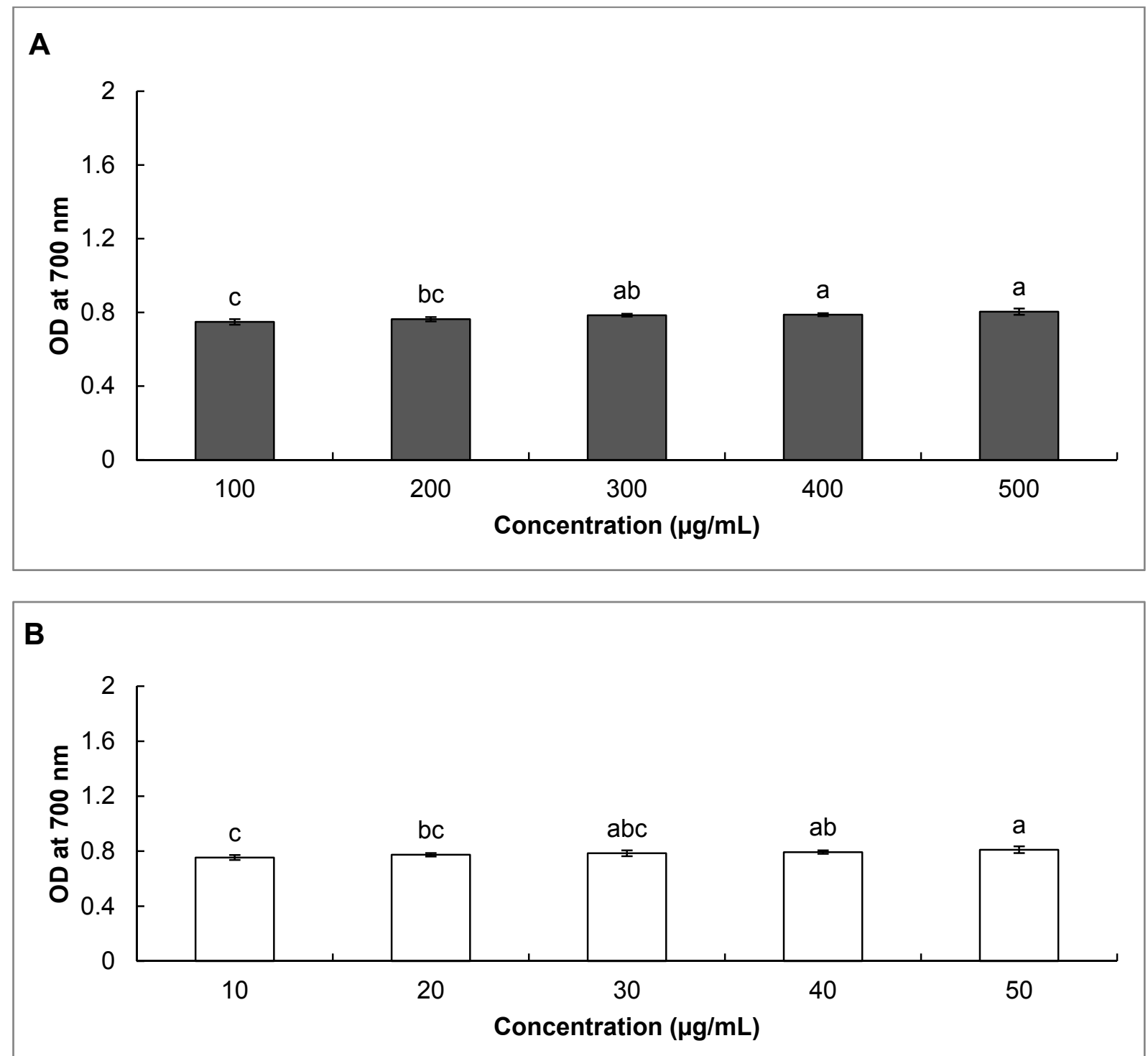

Figure 4. Reducing power of (A) Japanese red pine sawdust bio-oil (SBO) and (B) gallic acid as the reference. Columns with different superscript letters indicate a significant difference at $p<0.05$.

The total phenolic content of SBO was equivalent to $5.7 \%$ gallic acid based on the calculation curve (data not shown). On an average, the phenol content of pyrolysis liquid is only $2 \%-5 \%$ [68], however, SBO contained $5.7 \%$ of phenol content, which content can be considered as to be rich in phenolic content. The antioxidant potentials of different plant species were due to the presence of phenolic compounds [69].

The phenolic compounds in food have also been demonstrated to possess potential antioxidant activity [70]. Thus the antioxidant potential of SBO in the present study may be attributed to the presence of high levels of phenolic compounds that display potent antioxidant properties. The phenolic compounds with reducing potential and antioxidant property can inhibit the formation of superoxide anion radicals [71], thus the high amount of total phenol content of SBO could be correlated to its antioxidant potential. Food, pharmaceutical and cosmetic industries are increasing their interest in polyphenolic compounds, which have been shown to neutralize the effect of adverse free radicals with 
potential antioxidant properties and to prevent many diseases related to oxidative stress, such as aging, cancer, degenerative diseases, etc. [62,72].

Extracts of $P$. densiflora have been reported to possess strong antioxidant potential due to the presence of phenolic compounds such as catechin, taxifolin, epicatechin, condensed flavonoids (e.g., procyanidins), phenolic acids (ferrulic acid, caffeic acid, $p$-hydroxybenzoic acids), and tannins [18-23]. Thus the antioxidant potential of SBO could be attributed to the rich presence of phenolic compounds originated from the sawdust of $P$. densiflora and other chemical compounds produced from the manufacturing process. SBO with rich phenolic compounds could be considered as a potential candidate for the formulation of new nutraceuticals and skin care products for the cosmetic industries.

Certain antioxidant compounds, including phenolic antioxidants and tocopherols, have been shown to undergo loss of activity at high concentrations and become prooxidative or reactive [73]. The direct addition of antioxidant compounds to food products in higher doses results in a rapid depletion of the antioxidants in the long run. SBO could be an economic solution as an additive for developing polymer packaging materials which can deliver antioxidant compounds in a controlled manner throughout the product's shelf life.

\section{Experimental Section}

\subsection{Materials}

\subsubsection{Chemicals and Instruments}

All chemicals such as 2,2'-azino-bis[3-ethylbenzothiazoline-6-sulphonic acid] (ABTS), diphenyl-2-picrylhydraxyl (DPPH), sodium nitroprusside (SNP), Griess reagent, nitroblue tetrazolium (NBT), phenazine methosulphate (PMS), trichloroacetic acid (TCA), ferric chloride, potassium ferricyanide and gallic acid were of analytical grade and purchased from Sigma Aldrich (St. Louis, MO, USA). Spectrophotometric measurements were performed using a 96-well multimode microplate reader (Infinite M200 PRO NanoQuant, Tecan, Mannedorf, Switzerland).

\subsubsection{Production of BO from Japanese Red Pine Sawdust}

Japanese red pine was obtained from Korea Forest Research Institute in the form of bark free wood chips, which were ground to sawdust and sieved to a particle size of $0.5 \mathrm{~mm}$. After being dried to $c a$. $7 \%$ moisture content, the sawdust was used as raw material for the manufacture of SBO in a lab-scale fluid-bed fast pyrolysis procedure. Fast pyrolysis of the sawdust was then performed at $500{ }^{\circ} \mathrm{C}$ in a nitrogen atmosphere with a pyrolysis product residence time of $1.3 \mathrm{~s}$ [74]. The manufactured SBO was kept at $4{ }^{\circ} \mathrm{C}$ until further analysis.

\subsection{Methods}

\subsubsection{Physical Analysis of SBO}

SBO obtained from the fast pyrolysis process was characterized by several analytical methods. The water content was determined using a Karl-Fisher titration unit with hydranal composite 5 solutions. 
The composition of carbon, hydrogen, and nitrogen present in the manufactured SBO was analyzed by an elemental analyzer (FLASH $2000 \mathrm{CHNS} / \mathrm{O}$ Analyzers, Thermo Fisher Scientific, Waltham, MA, USA) and the ratio of oxygen was calculated based on the difference. The higher heating values (HHV) of SBO were estimated according to the Sheng and Azevedo's correlation [75]. Total acid number (TAN) and kinetic viscosity at $40{ }^{\circ} \mathrm{C}$ were determined by a titrator ( 848 Titrino plus, Metrohm, Herisau, Switzerland) using 0.1 M KOH and a capillary viscometer, respectively.

\subsubsection{Chemical Analysis of the Volatile Compounds in SBO}

The chemical composition of volatile compounds in SBO was determined by gas chromatography and mass spectra analysis using a GC-MS system (Jeol JMS 700 MStation, Jeol USA, Peabody, MA, USA) equipped with an Agilent 6890N GC DB-5 MS fused silica capillary column $(30 \mathrm{~m} \times 0.25 \mathrm{~mm}$ i.d. and film thickness of $0.25 \mu \mathrm{m}$ ). For GC-MS detection, an electron ionization system with ionization energy of $70 \mathrm{eV}$ was used and helium was applied at a constant flow rate of $1 \mathrm{~mL} / \mathrm{min}$ as the carrier gas. The temperature of the injector and MS transfer line was set at $280{ }^{\circ} \mathrm{C}$ and $250{ }^{\circ} \mathrm{C}$, respectively. Initially, the oven temperature was maintained at $50{ }^{\circ} \mathrm{C}$ for $2 \mathrm{~min}$, after which it was increased to $250{ }^{\circ} \mathrm{C}$ at a rate of $10{ }^{\circ} \mathrm{C} / \mathrm{min}$, where it was held for $10 \mathrm{~min}$. Samples ( $1 \mu \mathrm{L}$ of 100 times-diluted samples in methanol) were injected manually in splitless mode through the injector. The relative percentages of the constituents of SBO were expressed as percentages calculated by normalization of the peak area. Identification of various volatile compounds in SBO was based on the GC retention time on a DB-5 capillary column relative to computer matching of mass spectra using the Wiley and National Institute of Standards and Technology libraries for the GC-MS system [76]. The chemical structures of some of the medicinally important compounds were drawn using the ACD Chemsketch software [77].

\subsubsection{Radical Scavenging Potential of SBO}

The radical scavenging and antioxidant potential of the crude SBO was determined by DPPH radical, ABTS radical, hydroxyl radical, superoxide anion and nitric oxide scavenging assays, as well as lipid peroxidation inhibition and reducing power assays.

DPPH Radical Scavenging Activity of SBO

The DPPH free radical scavenging potential of SBO was determined as per the standard procedure, with slight modification [78]. Briefly, $50 \mu \mathrm{L}$ of different concentrations of SBO $(100-500 \mu \mathrm{g} / \mathrm{mL})$ or gallic acid $(10-50 \mu \mathrm{g} / \mathrm{mL})$ were added to $50 \mu \mathrm{L}$ of $0.1 \mathrm{mM}$ DPPH in methanol in a 96 -well flat bottom microplate (SPL Life Sciences, Pocheon-si, Gyeonggi-do, South Korea). A mixture of $50 \mu \mathrm{L}$ each of methanol and $0.1 \mathrm{mM}$ DPPH solution was taken as the control. The reaction mixture was incubated at $37^{\circ} \mathrm{C}$ for $30 \mathrm{~min}$ in darkness with shaking at $150 \mathrm{rpm}$, after which the absorbance of the sample was taken at $517 \mathrm{~nm}$ using the 96-well microplate reader. The concentration of SBO to scavenge $50 \%$ of $\mathrm{DPPH}$ radical was calculated as $\mathrm{IC}_{50}$ values from the regression analysis. 


\section{ABTS Radical Scavenging Activity of SBO}

The ABTS free radical scavenging potential of the SBO was determined by the standard procedure, with slight modification [51]. Prior to the experiment, stock solutions of $7.4 \mathrm{mM}$ ABTS solution and $2.6 \mathrm{mM}$ potassium persulfate solution were prepared in separate bottles and kept in darkness. The required amount of the two stock solutions was mixed equally and allowed to react for $12 \mathrm{~h}$ in darkness to manufacture the ABTS working solution. Next, $15 \mu \mathrm{L}$ of different concentrations of SBO $(100-500 \mu \mathrm{g} / \mathrm{mL})$ or gallic acid $(10-50 \mu \mathrm{g} / \mathrm{mL})$ was added to $285 \mu \mathrm{L}$ of the ABTS working solution and kept in the dark for $2 \mathrm{~h}$. Reaction mixture amended with $15 \mu \mathrm{L}$ of methanol and $285 \mu \mathrm{L}$ of the ABTS working solution was taken as the control. The absorbance of the reaction mixture was taken at $730 \mathrm{~nm}$ using a 96-well microplate reader. The result was represented in terms of IC50 values (concentration of SBO scavenging $50 \%$ of ABTS radicals).

\section{Hydroxyl Radical Scavenging Activity of SBO}

The hydroxyl radical scavenging potential of SBO was determined by a standard procedure [79]. The total volume of the reaction mixture $(240 \mu \mathrm{L})$ contained $3 \mathrm{mM}$ 2-deoxyribose, $20 \mathrm{mM}$ potassium phosphate buffer ( $\mathrm{pH} 7.4$ ), $0.1 \mathrm{mM}$ ferric chloride, $0.1 \mathrm{mM}$ ethylenediamine tetraacetic acid, $2 \mathrm{mM}$ hydrogen peroxide, $0.1 \mathrm{mM}$ ascorbic acid, and $40 \mu \mathrm{L}$ of various concentrations of SBO $(100-500 \mu \mathrm{g} / \mathrm{mL})$ or gallic acid $(10-50 \mu \mathrm{g} / \mathrm{mL})$. After incubating the reaction mixture at $37^{\circ} \mathrm{C}$ for $45 \mathrm{~min}, 40 \mu \mathrm{L}$ each of $2.8 \%$ TCA and $0.5 \%$ TBA in $0.025 \mathrm{M}$ sodium hydroxide solution containing $0.02 \%$ BHA were added and incubated at $90{ }^{\circ} \mathrm{C}$ for 15 min to develop a pink color. The mixture was then allowed to cool, after which the absorbance was measured at $532 \mathrm{~nm}$. The reaction mixture amended with $40 \mu \mathrm{L}$ methanol was taken as a control. The hydroxyl radical scavenging potential of SBO was represented in terms of $\mathrm{IC}_{50}$ values, which was calculated by the regression curve analysis.

\section{Superoxide Anion Scavenging Activity of SBO}

The superoxide anion scavenging potential of SBO was evaluated by measuring the reduction of NBT [80]. The total volume of the reaction mixture $(100 \mu \mathrm{L})$ contained $40 \mu \mathrm{L}$ of $0.02 \mathrm{M}$ phosphate buffer (pH 7.4), $10 \mu \mathrm{L}$ of $73 \mu \mathrm{M} \mathrm{NADH}, 10 \mu \mathrm{L}$ of $50 \mu \mathrm{M}$ NBT, $10 \mu \mathrm{L}$ of $15 \mu \mathrm{M}$ PMS and $30 \mu \mathrm{L}$ of various concentrations of SBO $(100-500 \mu \mathrm{g} / \mathrm{mL})$ or gallic acid $(10-50 \mu \mathrm{g} / \mathrm{mL})$ as the standard. The mixture was incubated for $60 \mathrm{~min}$ at room temperature, after which the quantity of formazan generated was determined by taking the absorbance of the reaction mixture at $560 \mathrm{~nm}$. Reaction mixture amended with only $30 \mu \mathrm{L}$ of methanol was taken as a control. The superoxide radical scavenging potential of SBO was calculated in terms of $\mathrm{IC}_{50}$ value, which was calculated by the regression curve analysis.

\section{Nitric Oxide Scavenging Activity of SBO}

The nitric oxide radical scavenging potential of SBO was determined by the standard method [24]. The reaction mixture of $200 \mu \mathrm{L}$ consisted of $100 \mu \mathrm{L}$ of different concentrations of SBO $(100-500 \mu \mathrm{g} / \mathrm{mL})$ or gallic acid $(10-50 \mu \mathrm{g} / \mathrm{mL})$ and $100 \mu \mathrm{L}$ of $10 \mathrm{mM}$ sodium nitroprusside in phosphate buffer saline (pH 7.4). The mixture was incubated at $37{ }^{\circ} \mathrm{C}$ for $60 \mathrm{~min}$ in light, after which $75 \mu \mathrm{L}$ aliquots of the reaction mixture were mixed with $75 \mu \mathrm{L}$ of Griess reagent $(1.0 \%$ sulfanilamide and $0.1 \%$ napthyl 
ethylenediamine dihydrochloride) and then incubated at $25{ }^{\circ} \mathrm{C}$ for $30 \mathrm{~min}$ in darkness. The absorbance was then measured at $546 \mathrm{~nm}$. Reaction mixture amended with only $100 \mu \mathrm{L}$ methanol was taken as a control. The nitric oxide scavenging potential of SBO was represented by $\mathrm{IC}_{50}$ values, which was calculated by the regression curve analysis.

\subsubsection{Inhibition of Lipid Peroxidation Activity of SBO}

The inhibition of lipid peroxidation by SBO was assayed by the $\mathrm{Fe}^{3+}$ /ascorbic acid-dependent non enzymatic lipid peroxidation method using bovine brain extract as previously described, with slight modification [81]. Briefly, a $100 \mu \mathrm{L}$ reaction mixture consisting of $30 \mu \mathrm{L}$ of SBO $(100-500 \mu \mathrm{g} / \mathrm{mL})$ or gallic acid $(10-50 \mu \mathrm{g} / \mathrm{mL})$ at different concentrations, $50 \mu \mathrm{L}$ of bovine brain phospholipids $(5 \mathrm{mg} / \mathrm{mL})$, $10 \mu \mathrm{L}$ of $1 \mathrm{mM} \mathrm{FeCl}_{3}$ and $10 \mu \mathrm{L}$ of $1 \mathrm{mM}$ ascorbic acid in $20 \mathrm{mM}$ phosphate buffer. The mixture was incubated at $37{ }^{\circ} \mathrm{C}$ for $1 \mathrm{~h}$. After incubation, $100 \mu \mathrm{L}$ each of $1 \%$ TBA and $30 \%$ TCA acid and $10 \mu \mathrm{L}$ of $4 \%$ BHT was added and the sample was heated in boiling water for $20 \mathrm{~min}$. The absorbance was then measured at $532 \mathrm{~nm}$ using the 96-well microplate reader, after which the percent inhibition of lipid peroxidation was calculated using the following formula:

$$
\text { Inhibition of lipid peroxidation }(\%)=\left[\left(\mathrm{A}_{0}-\mathrm{A}_{\mathrm{t}}\right) / \mathrm{A}_{0}\right] \times 100
$$

where, $\mathrm{A}_{0}$ is the absorbance of the control and $\mathrm{A}_{t}$ is the absorbance of the treatment.

\subsubsection{Reducing Power of SBO}

The $\mathrm{Fe}^{3+}$ reducing power of SBO was determined as previously described [82]. Briefly, $50 \mu \mathrm{L}$ of SBO $(100-500 \mu \mathrm{g} / \mathrm{mL})$ or gallic acid $(10-50 \mu \mathrm{g} / \mathrm{mL})$ was mixed with $50 \mu \mathrm{L}$ of $0.2 \mathrm{M}$ phosphate buffer (pH 6.6) and $50 \mu \mathrm{L}$ of $1 \%$ potassium ferricyanide. The mixture solution was then incubated at $50{ }^{\circ} \mathrm{C}$ for $20 \mathrm{~min}$ in darkness. After incubation, $50 \mu \mathrm{L}$ of $10 \%$ TCA was added to terminate the reaction and the mixture was centrifuged at $3000 \mathrm{rpm}$ for $10 \mathrm{~min}$. Next, $50 \mu \mathrm{L}$ of supernatant was mixed with $50 \mu \mathrm{L}$ of distilled water and $10 \mu \mathrm{L}$ of $0.1 \% \mathrm{FeCl}_{3}$ solution and incubated for $10 \mathrm{~min}$ at room temperature. Finally, the absorbance was measured at $700 \mathrm{~nm}$ and the result was expressed in terms of absorbance at $700 \mathrm{~nm}$.

\subsubsection{Total Phenolic Content of SBO}

The Folin-Ciocalteu method was used to measure the total phenolic content of SBO [83]. Briefly, $50 \mu \mathrm{L}$ of SBO corresponding to $0.1 \mathrm{mg} / \mathrm{mL}$ was mixed with $50 \mu \mathrm{L}$ of $50 \%$ Folin-Ciocalteu reagent. After incubating the mixture at $25{ }^{\circ} \mathrm{C}$ for 5 min in darkness, $100 \mu \mathrm{L}$ of $20 \% \mathrm{Na}_{2} \mathrm{CO}_{3}$ solution was added and the sample was incubated for an additional $20 \mathrm{~min}$ at $25^{\circ} \mathrm{C}$ for $20 \mathrm{~min}$. Finally, the absorbance of the reaction mixture was measured at $730 \mathrm{~nm}$ and the total phenolic content was determined from the standard calibration curve of gallic acid using a concentration range of 5-50 $\mu \mathrm{g} / \mathrm{mL}$.

\subsubsection{Statistical Analysis}

All results were expressed as the mean \pm standard deviation (SD) based on three independent replicates. Statistical interpretation of the results to test the significance of differences between means 
obtained among the treatments was conducted by one-way analysis of variance (ANOVA) followed by Duncan's test at the $5 \%$ level of significance $(p<0.05)$ using the Statistical Analysis Software (SAS) (Version: SAS 9.2, SAS Institute Inc., Cary, NC, USA).

\section{Conclusions}

The results of the present study demonstrate that SBO manufactured by pyrolysis of Japanese red pine sawdust contains phenolic compounds, acids, furans and other aromatic compounds. It possesses significant antioxidant potential that occurs via free radical scavenging, inhibition of lipid peroxidation and reducing power. SBO contains various useful compounds that could be used as a flavoring agent and food additive giving smoked, roasted and grilled flavor to food products. Apart from this, it can be utilized by the packaging industry as an additive for polymer packaging materials and by the pharmaceutical and cosmetic industries for use in preparation of useful compounds, medicines and sunscreens, and anti-aging, anti-wrinkle lotions with antioxidant potential.

\section{Acknowledgment}

This work was carried out with the support of "Cooperative Research Program for Agriculture Science \& Technology Development (Project No. PJ010934)” Rural Development Administration, Republic of Korea.

\section{Authors Contributions}

J.K.P. has contributed in performing experiments and writing the manuscript. S.H.K. and H.H. contributed to the chemical and physical analysis of samples. K.H.B. and J.W.C. contributed in planning and designing the study and analysis of data. All authors participated in drafting the manuscript; they have read and approved the final manuscript.

\section{Conflicts of Interest}

The authors declare no conflict of interest.

\section{References}

1. Rajamanikandan, S.; Sindhu, T.; Durgapriya, D.; Sophia, D.; Ragavendran, P.; Gopalkrishnan, V.K. Radical scavenging and antioxidant activity of ethanolic extract of Mollugo nudicaulis by in vitro assays. Indian J. Pharm. Educ. Res. 2011, 45, 310-316.

2. Gulcin, I.; Oktay, M.; Kirecci, E.; Kufrevioglu, O.I. Screening of antioxidant and antimicrobial activities of anise (Pimpinella anisum L.) seed extracts. Food Chem. 2003, 83, 371-382.

3. Yildirim, A.; Mavi, A.; Kara, A.A. Determination of antioxidant and antimicrobial activities of Rumaxs crispus L. extracts. J. Agric. Food Chem. 2001, 49, 4083-4089.

4. Mandal, S.; Hazra, B.; Sarkar, R.; Biswas, S.; Mandal, N. Assessment of the antioxidant and reactive oxygen species scavenging activity of methanolic extract of Caesalphinia crista leaf. Evid. Based Complement. Altern. Med. 2011, 2011, 173768. 
5. Finkel, T.; Holbrook, N.J. Oxidants, oxidative stress and the biology of ageing. Nature 2000, 408, 239-247.

6. Thitilertdecha, N.; Teerawutgulrag, A.; Rakariyatham, N. Antioxidant and antibacterial activities of Nephelium lappaceum L. extracts. LWT Food Sci. Technol. 2008, 41, 2029-2035.

7. Valko, M.; Leibfritz, D.; Moncol, J.; Cronin, M.T.D.; Mazur, M.; Telser, J. Free radicals and antioxidants in normal physiological functions and human disease. Int. J. Biochem. Cell Biol. 2007, 39, 44-84.

8. Bajpai, V.K.; Sharma, A.; Kim, S.H.; Baek, K.H. Phenolic content and antioxidant capacity of essential oil obtained from sawdust of Chamaecyparis obtusa by microwave-assisted hydrodistillation. Food Technol. Biotechnol. 2013, 51, 360-369.

9. El, S.N.; Karakaya, S. Radical scavenging and iron chelating activities of some greens used as traditional dishes in Mediterranean diet. Int. J. Food. Sci. Nutr. 2004, 55, 67-74.

10. Karakaya, S.; El, S.N.; Karagozlu, N.; Sxahin, S. Antioxidant and antimicrobial activities of essential oils obtained from oregano (Origanum vulgare ssp. hirtum) by using different extraction methods. J. Med. Food. 2011, 14, 645-652.

11. Tepe, B.; Akpulat, H.A.; Sokmen, M.; Daferera, D.; Yumrutas, O.; Aydin, E.; Polissiou, M.; Sokmen, A. Screening of the antioxidative and antimicrobial properties of the essential oils of Pimpinella anisetum and Pimpinella flabellifolia from Turkey. Food Chem. 2006, 97, 719-724.

12. Huang, D.; Ou, B.; Prior, R.L. The chemistry behind antioxidant capacity assays. J. Agric. Food Chem. 2005, 53, 1841-1856.

13. Lee, H.M.; Khan, Z.; Kim, S.G.; Baek, N.I.; Kim, Y.H. Evaluation of the biocontrol potential of some medicinal plant materials alone and in combination with Trichoderma harzianum against Rhizoctonia solani AG 2-1. Plant Pathol. J. 2011, 27, 68-77.

14. Kim, J.S.; Chung, H.Y. Profiling of volatile components using gas chromatography-mass spectrometry in commercial pine needle (Pinus densiflora S. and Z.) powder. J. Food. Sci. Nutr. 2011, 16, 45-55.

15. Lee, J.G.; Lee, C.G.; Kang, J.J.; Buglass, A.J.; Lee, G.H. Determination of optimum conditions for the analysis of volatile components in pine needles by double-shot pyrolysis-gas chromatography-mass spectrometry. J. Chromatogr. A 2005, 1089, 227-234.

16. Jung, M.J.; Jung, H.A.; Kang, S.S.; Hwang, G.S.; Choi, J.S. A new abietic acid-type diterpene glucoside from the needles of Pinus densiflora. Arch. Pharm. Res. 2009, 32, 1699-1704.

17. Young, L.W.; Youngki, P.; Seung, C.H.; Kwon, A.J. Screening of antioxidant activity of domestic trees. Mokchae Konghak 2003, 31, 40-44.

18. Jiang, Y.; Han, W.; Shen, T.; Wang, M.H. Antioxidant activity and protection from dna damage by water extract from pine (Pinus densiflora) bark. Prev. Nutr. Food Sci. 2012, 17, 116-121.

19. Satoh, K.; Sakagami, H. Ascorbyl radical scavenging activity of polyphenols. Anticancer. Res. 1996, 16, 2885-2890.

20. Park, Y.S.; Jeon, M.H.; Hwang, H.J.; Park, M.R.; Lee, S.H.; Kim, S.G.; Kim, M. Antioxidant activity and analysis of proanthocyanidins from pine (Pinus densiflora) needles. Nutr. Res. Pract. 2011, 5, 281-287. 
21. Packer, L.; Rimbach, G.; Virgili, F. Antioxidant activity and biological properties of a procyanidin-rich extract from pine (Pinus maritima) bark, Pycnogenol. Free Radic. Biol. Med. 1999, 27, 704-724.

22. Cho, K.J.; Yun, C.H.; Yoon, D.Y.; Cho, Y.S.; Rimbach, G.; Packer, L.; Chung, A.S. Effect of bioflavonoids extracted from the bark of Pinus maritima on proinflammatory cytokine interleukin-1 production in lipopolysaccharide-stimulated RAW 264.7. Toxicol. Appl. Pharmacol. 2000, 168, 64-71.

23. Iravani, S.; Zolfaghari, B. Pharmaceutical and nutraceutical effects of Pinus pinaster bark extract. Res. Pharm. Sci. 2011, 6, 1-11.

24. Bajpai, V.K.; Sharma, A.; Kim, S.H.; Kim, Y.; Kim, J.J.; Baek, K.H. Microwave-assisted seed essential oil of Eleutherococcus senticosus and its antioxidant and free radical-scavenging activities. J. Food Biochem. 2013, 37, 119-127.

25. Demirbas, A. Biodiesel: A Realistic Fuel Alternative for Diesel Engines; Springer-Verlag London Limited: London, UK, 2007.

26. Lemoine, F.; Maupin, I.; Lemee, L.; Lavoie, J.M.; Lemberton, J.L.; Pouilloux, Y.; Pinard, L. Alternative fuel production by catalytic hydroliquefaction of solid municipal wastes, primary sludges and microalgae. Bioresour. Technol. 2013, 142, 1-8.

27. Fiege, H. Cresols and Xylenols. In Ullmann's Encyclopedia of Industrial Chemistry; Wiley-VCH Verlas GmbH \& Co.: Weinhenim, Germany, 2000.

28. Lee, J.C.; Song, I.G.; Park, J.Y. Microwave promoted facile synthesis of methyl and ethyl carboxylates. Synth. Commun. 2002, 32, 2209-2213.

29. Li, N.G.; Shi, Z.H.; Tang, Y.P.; Li, B.Q.; Duan, J.A. Highly efficient esterification of ferulic acid under microwave irradiation. Molecules 2009, 14, 2118-2126.

30. Elavarasan, P.; Kondamudi, K.; Upadhyayula, S. Synthesis of antioxidants: Green chemistry route. Int. J. Chem. Sci. 2010, 8, S578-S584.

31. Bedmutha, R.; Booker, C.J.; Ferrante, L.; Briens, C.; Berruti, F.; Yeung, K.K.C.; Scott, I.; Conn, K. Insecticidal and bactericidal characteristics of the bio-oil from the fast pyrolysis of coffee grounds. J. Anal. Appl. Pyrol. 2011, 90, 224-231.

32. Guo, Z.; Wang, S.; Xu, G.; Cai, Q. Upgrading of bio-oil molecular distillation fraction with solid acid catalyst. BioResources 2011, 6, 2539-2550.

33. Hamieh, S.; Beauchet, R.; Lemee, L.; Toufaily, J.; Koubaissy, B.; Hamieh, T.; Pouilloux, Y.; Pinard, L. Bio-oil synthesis by coupling biological biomass pretreatment and catalytic hydroliquefaction process. Bioresour. Technol. 2014, 156, 389-394.

34. Phukan, M.M.; Chutia, R.S.; Kumar, R.; Kalita, D.; Konwar, B.K.; Kataki, R. Assessment of antimicrobial activity of bio-oil from Pongamia glabra, Mesua ferrea and Parachlorella spp deoiled cake. Int. J. Pharm. Biol. Sci. 2013, 4, 910-918.

35. Marshall, A.J. Commercial Application of Pyrolysis Technology in Agriculture; Ontario Federation of Agriculture. Ontario AgriCentre: Guelph, ON, Canada, 2013.

36. Ksouri, R.; Falleh, H.; Megdiche, W.; Trabelsi, N.; Mhamdi, B.; Chaieb, K.; Bakrouf, A.; Magne, C.; Abdelly, C. Antioxidant and antimicrobial activities of the edible medicinal halophyte Tamarix gallica L. and related polyphenolic constituents. Food Chem. Toxicol. 2009, 47, 2083-2091. 
37. Bridgwater, A.V.; Meier, D.; Radlein, D. An overview of fast pyrolysis of biomass. Org. Geochem. 1999, 30, 1479-1493.

38. Oasmaa, A.; Elliott, D.C.; Korhonen, J. Acidity of biomass fast pyrolysis bio-oils. Energy Fuels 2010, 24, 6548-6554.

39. Dobele, G.; Dizhbite, T.; Ponomarenko, J.; Urbanovich, I.; Kreicberga, J.; Valdis, K. Isolation and characterization of the phenolic fractions of wood pyrolytic oil. Holzforschung 2011, 65, 503-510.

40. Tessarola, N.S.; Dos-Santos, L.R.M.; Silva, R.S.F.; Azevedo, D.A. Chemical characterization of bio-oils using comprehensive two-dimensional gas chromatography with time-of-flight mass spectrometry. J. Chromatogr. A 2013, 1279, 68-75.

41. Xu, Y.; Hu, X.; Li, W.; Shi, Y. Preparation and characterization of bio-oil from biomass. In Progress in Biomass and Bioenergy Production; Shaukat, S.S., Ed.; InTech Publisher: Rijeka, Croatia, 2011; pp. 197-222.

42. Wildschut, J. Pyrolysis oil Upgrading to Transportation Fuels by Catalytic Hydrotreatmen. Ph.D. Thesis, University of Groningen, Groningen, The Netherlands, 2009.

43. Hoyle, W.; Roberts, G.P. Potential antimicrobial furans. J. Med. Chem. 1973, 16, 709-710.

44. Meotti, F.C.; Silva, D.O.; Dos-Santos, A.R.S.; Zeni, G.; Rocha, J.B.T.; Nogueira, C.W. Thiophenes and furans derivatives: A new class of potential pharmacological agents. Environ. Toxicol. Pharmacol. 2003, 15, 37-44.

45. Verma, A.; Pandeya, S.N.; Sinha, S. Synthesis and biological activities of furan derivatives. Int. J. Res. Ayurveda Pharm. 2011, 2, 1110-1116.

46. Lam, R.Y.Y.; Lin, Z.X.; Sviderskaya, E.V.; Cheng, C.H.K. Mechanistic studies of anti-hyperpigmentary compounds: Elucidating their inhibitory and regulatory actions. Int. J. Mol. Sci. 2014, 15, 14649-14668.

47. Kim, K.H.; Eom, I.Y.; Lee, S.M.; Choi, D.; Yeo, H.; Choi, I.G.; Choi, J.W. Investigation of physicochemical properties of bio-oils produced from yellow poplar wood (Liriodendron tulipifera) at various temperatures and residence times. J. Anal. Appl. Pyrol. 2011, 92, 2-9.

48. Syazana, M.S.N.; Halim, A.S.; Gan, S.H.; Shamsuddin, S. Antiproliferative effect of methanolic extraction of tualang honey on human keloid fibroblasts. BMC Complement. Altern. Med. 2011, 11,82 .

49. Ensyn Group, Inc. Available online: www.ensyn.com/ (accessed on 28 February 2015).

50. Moraes, M.S.A.; Migliorini, M.V.; Damasceno, F.C.; Georges, F.; Almeida, S.; Zini, C.A.; Jacques, R.A.; Caramao, E.B. Qualitative analysis of bio oils of agricultural residues obtained through pyrolysis using comprehensive two dimensional gas chromatography with time-of-flight mass spectrometric detector. J. Anal. Appl. Pyrol. 2012, 98, 51-64.

51. Arnao, M.B.; Cano, A.; Acosta, M. The hydrophilic and lipophilic contribution to total antioxidant activity. Food Chem. 2001, 73, 239-244.

52. Adedapo, A.A.; Jimoh, F.O.; Afolayan, A.J.; Masika, P.J. Antioxidant activities and phenolic contents of the methanol extracts of the stems of Acokanthera oppositifolia and Adenia gummifera. BMC Complement. Altern. Med. 2008, 8, 54. 
53. Abed, N.E.; Kaabi, B.; Smaali, M.I.; Chabbouh, M.; Habibi, K.; Mejri, M.; Marzouki, M.N.; Ahmed, S.B.H. Chemical Composition, Antioxidant and Antimicrobial Activities of Thymus capitata Essential Oil with Its Preservative Effect against Listeria monocytogenes Inoculated in Minced Beef Meat. Evid. Based Complement. Altern. Med. 2014, 2014, 11.

54. Gursoy, N.; Tepe, B.; Akpulat, H.A. Chemical composition and antioxidant activity of the essential oils of Salvia palaestina (Bentham) and S. ceratophylla (L.). Rec. Nat. Prod. 2012, 6, 278-287.

55. Brewer, M.S. Natural antioxidants: Sources, compounds, mechanism of action, and potential applications. Compr. Rev. Food Sci. Food Saf. 2011, 10, 221-247.

56. Ogunjobi, J.K.; Lajide, L. Characterisation of Bio-Oil and Bio-Char from Slow-Pyrolysed Nigerian Yellow and White Corn Cobs. J. Sustain. Energy Environ. 2013, 4, 77-84.

57. Halliwell, B.; Gutteridge, J. Free Radicals in Biology and Medicine; Oxford University Press: Oxford, UK, 2007.

58. Pietta, P.G. Flavonoids as antioxidants. J. Nat. Prod. 2000, 63, 1035-1042.

59. Cheng, R.; Glynn, S.; Santana, W.F.; Switzer, C.; Ridnour, L.; Wink, D.A. Nitric oxide and redox inflammation in cancer. Adv. Mol. Toxicol. 2010, 4, 157-182.

60. Cals-Grierson, M.M.; Ormerod, A.D. Nitric oxide function in the skin. Nitric Oxide 2004, 10, 179-193.

61. Soneja, A.; Drews, M.; Malinski, T. Role of nitric oxide, nitroxidative and oxidative stress in wound healing. Pharmacol. Rep. 2005, 57, 108-119.

62. Royer, M.; Prado, M.; Garcia-Perez, M.E.; Diouf, P.N.; Stevanovic, T. Study of nutraceutical, nutricosmetics and cosmeceutical potentials of polyphenolic bark extracts from Canadian forest species. Pharm. Nutr. 2013, 1, 158-167.

63. Sun, Y.E.; Wang, W.D.; Chen, H.W.; Li, C. Autoxidation of unsaturated lipids in food emulsion. Crit. Rev. Food Sci. Nutr. 2011, 51, 453-466.

64. Dauqan, E.M.A.; Abdullah, A.; Sani, H.A. Natural antioxidants, lipid profile, lipid peroxidation, antioxidant enzymes of different vegetable oils. Adv. J. Food Sci. Technol. 2011, 3, 308-316.

65. Kohen, R. Skin antioxidants: Their role in aging and in oxidative stress-New approaches for their evaluation. Biomed. Pharmacol. 1999, 53, 181-192.

66. Sasipriya, G.; Siddhuraju, P. Effect of different processing methods on antioxidant activity of underutilized legumes, Entada scandens seed kernel and Canavalia gladiate seeds. Food Chem. Toxicol. 2012, 50, 2864-2872.

67. Wang, H.F.; Yih, K.H.; Huang, K.F. Comparative study of the antioxidant activity of forty-five commonly used essential oils and their potential active components. J. Food Drug Anal. 2010, 18, 24-33.

68. Radlein, D. The production of chemicals from fast pyrolysis bio-oils. In Fast Pyrolysis of Biomass; Bridgewater, A., Ed.; CPL Press: Newbury, UK, 1999.

69. Kunyanga, C.N.; Imungi, J.K.; Okoth, M.W.; Biesalski, H.K.; Vadivel, V. Total phenolic content, antioxidant and antidiabetic properties of methanolic extract of raw and traditionally processed Kenyan indigenous food ingredients. LWT Food Sci. Technol. 2012, 45, 269-276.

70. Soong, Y.Y.; Barlow, P.J. Antioxidant activity and phenolic content of selected fruit seeds. Food Chem. 2004, 88, 411-417. 
71. Bursal, E.; Gulcin, I. Polyphenol contents and in vitro antioxidant activities of lyophilised aqueous extract of kiwifruit (Actinidia deliciosa). Food Res. Int. 2011, 44, 1482-1489.

72. Stevanovic, T.; Diouf, P.N.; Garcia-Perez, M.E. Bioactive polyphenols from healthy diets and forest biomass. Curr. Nutr. Food Sci. 2010, 5, 264-295.

73. Jadhav, S.J.; Nimbalkar, S.S.; Kulkarni, A.D.; Madhavi, D.L. Lipid oxidation in biological and food systems. In Food Antioxidants: Technological, Toxicological, and Health Perspectives; Madhavi, D.L., Deshpande, S.S., Salunkhe, D.K., Eds.; Marcel Dekker: New York, NY, USA, 1996; pp. 5-63.

74. Hwang, H.; Shinyoung, O.; Cho, T.S.; Choi, I.G.; Choi, J.W. Fast pyrolysis of potassium impregnated poplar wood and characterization of its influence on the formation as well as properties of pyrolytic products. Bioresour. Technol. 2013, 150, 359-366.

75. Sheng, C.; Azevedo, J.L.T. Estimating the higher heating value of biomass fuels from basic analysis data. Biomass Bioenergy 2005, 28, 499-507.

76. Adams, R.P. Identification of Essential Oil Components by Gas Chromatography/Quadrupole Mass Spectroscopy; Allured Publishing Corporation: Carol Stream, IL, USA, 2001.

77. ACD/ChemSketch for Academic and Personal Use. Available online: http://www.acdlabs.com/ resources/freeware/chemsketch/ (accessed on 28 February 2015).

78. Braca, A.; Tommasi, N.D.; Bari, L.D.; Pizza, C.; Politi, M.; Morelli, I. Antioxidant principles from Bauhinia tarapotensis. J. Nat. Prod. 2001, 64, 892-895.

79. Elizabeth, K.; Rao, M.N.A. Oxygen radical scavenging activity of curcumin. Int. J. Pharm. 1990, 58, 237-240.

80. Fontana, M.; Mosca, L.; Rosei, M.A. Interaction of enkephalines with oxyradicals. Biochem. Pharmacol. 2001, 61, 1253-1257.

81. Houghton, P.J.; Zarka, R.; De las Heras, B.; Hoult, J.R.S. Fixed oil of Nigella sativa and derived thymoquinone inhibit eicosanoid generation in leukocytes and membrane lipid peroxidation. Planta Med. 1995, 61, 33-36.

82. Oyaizu, M. Studies on product of browning reactions prepared from glucose amine. Jpn. J. Nutr. 1986, 44, 307-315.

83. Kujala, T.S.; Loponen, J.M.; Klika, K.D.; Pihlaja, K. Phenolic and betacyanins in red beetroot (Beta vulgaris) root: Distribution and effects of cold storage on the content of total phenolics and three individual compounds. J. Agric. Food Chem. 2000, 48, 5338-5342.

Sample Availability: Bio-oil samples are available from the authors.

(C) 2015 by the authors; licensee MDPI, Basel, Switzerland. This article is an open access article distributed under the terms and conditions of the Creative Commons Attribution license (http://creativecommons.org/licenses/by/4.0/). 